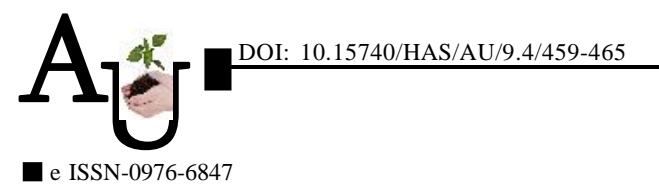

Research Article

\title{
Impact assessment of rice production technology recommended by Assam Agricultural University in terms of structural changes and cropping intensity in Assam
}

\author{
S. BORTHAKUR, P. MISHRA AND D. BORTAMULY
}

Article Chronicle:

Received :

12.07.2014;

Revised :

15.08.2014;

Accepted :

01.09.2014

\section{KeY Words :}

Impact assessment, Structural changes,

Cropping intensity
SUMMARY : A study was conducted in the districts of Karimganj, Lakhimpur and Jorhat of Assam to assess the impact of AAU recommended rice production technology in terms of structural changes occurring in farmer fields in Assam. A purposive sampling technique was followed and statistical methods such as percentage, frequency, mean and ranking was used for analysing the data. Data were collected through personal interview method during the period from late 2009 to early 2010. A total of 360 respondents were interviewed with the help of the structured schedule. About 12.50 per cent sample farmers had Kutcha irrigation channels throughout the three years covered under the study. In terms of farm machinery, 67.50 per cent respondents had sprayers and 48.61 per cent had weeders. Also, 36.67 per cent respondents had tube wells while 19.72 per cent and 3.33 per cent respondents had pump sets and dusters, respectively. About 1.39 per cent respondents also had threshers. Among the sampled respondents 4.17 per cent had power tillers and 0.28 per cent had tractors. Moreover, 93.61 per cent respondents possessed improved mud boundaries. It was seen that the total average cropping intensity in relation to rice in the study area was 108.90 per cent. Among the three districts covered under the study Lakhimpur had the highest average cropping intensity in relation to rice (120.82\%) followed by Karimganj $(106.58 \%)$ and Jorhat $(99.30 \%)$.

How to cite this article : Borthakur, S., Mishra, P. and Bortamuly, D. (2014). Impact assessment of rice production technology recommended by Assam Agricultural University in terms of structural changes and cropping intensity in Assam. Agric. Update, 9(4): 459-465.
Author for correspondence :

\section{S. BORTHAKUR}

Department of of Extension Education, faculty of Agriculture (AAU), JORHAT (ASSAM) INDIA

See end of the article for authors' affiliations 